\title{
Comparison of SARS-COV-2 nasal antigen test to nasopharyngeal RT-PCR in mildly symptomatic patients
}

Abdulkarim Abdulrahman ${ }^{1,2}$, Fathi Mustafa ${ }^{1,3}$, Abdulla I AlAwadhi $i^{1,4}$,

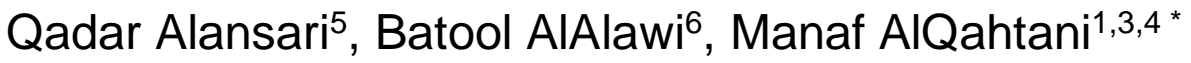

${ }^{1}$ National Taskforce for Combating the Coronavirus (COVID-19), Bahrain

2 Mohammed Bin Khalifa Cardiac Centre, Bahrain

${ }^{3}$ Royal College of Surgeons in Ireland, Bahrain

${ }^{4}$ Bahrain Defence Force hospital, Bahrain

${ }^{5}$ Ministry of Finance and National Economy, Bahrain

${ }^{6}$ Ministry of Health, Bahrain

${ }^{*}$ Corresponding author: Manaf AIQahtani.

Email:drmanaf@gmail.com

Phone: +973 39766000

Conflict of interest Disclosures. The authors have declared that no conflict of interest exists.

Funding/Support: None 
medRxiv preprint doi: https://doi.org/10.1101/2020.11.10.20228973; this version posted December 8, 2020. The copyright holder for this preprint (which was not certified by peer review) is the author/funder, who has granted medRxiv a license to display the preprint in It is made available under a CC-BY-NC-ND 4.0 International license .

\begin{abstract}
Introduction

COVID 19 has been vastly spreading since December 2019 and the medical teams worldwide are doing their best to limit its spread. In the absence of a vaccine the best way to fight it is by detecting infected cases early and isolate them to prevent its spread. Therefore, a readily available, rapid, and cost-effective test with high specificity and sensitivity for early detection of COVID 19 is required. In this study, we are testing the diagnostic performance of a rapid antigen detection test in mildly symptomatic cases. (RADT).
\end{abstract}

\title{
Methods
}

The study included 4183 patients who were mildly symptomatic. A nasal sample for the rapid antigen test and a nasopharyngeal sample was taken from each patient. Statistical analysis was conducted to calculate the sensitivity, specificity, positive predictive value, negative predictive value and kappa coefficient of agreement.

\section{Results}

The prevalence of COVID 19 in the study population was $17.5 \%(733 / 4183)$. The calculated sensitivity and specificity were $82.1 \%$ and $99.1 \%$ respectively. Kappa's coefficient of agreement between the rapid antigen test and RT-PCR was $0.859(p<0.001)$. A stratified analysis was performed and it showed that the sensitivity of the test improved significantly with lowering the cutoff $\mathrm{Ct}$ value to 24 .

\section{Conclusion}

The results of the diagnostic assessment of nasal swabs in the RADT used in our study are promising regarding the potential benefit of using them as a screening tool in mildly symptomatic patients. The diagnostic ability was especially high in cases with high viral load. The rapid antigen test is intended to be used alongside RT-PCR and not replace it. RADT can be of benefit in reducing the use of PCR. 
medRxiv preprint doi: https://doi.org/10.1101/2020.11.10.20228973; this version posted December $8,2020$. The copyright holder for this
preprint (which was not certified by peer review) is the author/funder, who has granted medRxiv a license to display the preprint in It is made available under a CC-BY-NC-ND 4.0 International license .

\section{Introduction:}

Since December 2019, the number of Coronavirus disease (COVID 19) confirmed cases has been rising swiftly despite the efforts to limit its spread. 1,2 The World Health Organization declared COVID 19 to be a pandemic on $12^{\text {th }}$ March $2020 .^{2}$ To date, the total number of cases and deaths worldwide has exceeded 50 million and 1 million, respectively. ${ }^{3}$ The medical team in Bahrain has been working diligently to confine the spread of this disease since the pandemic started. Bahrain have had more than 83000 COVID19 cases, with about of $5.56 \%$ of the population affected. ${ }^{4}$

The best way to battle this virus in the absence of an effective vaccine is the ability to detect infections early enough to take the necessary precautions to halt its spread to contacts and adequately manage high-risk patients. What is challenging about that is the lack of a readily available, rapid, and cost-effective test with high specificity and sensitivity for early detection of COVID 19 infected patients in the general population. ${ }^{5-8}$

Until now, nasopharyngeal Real Time - Polymerase Chain Reaction (RT-PCR) is the gold standard diagnostic test for COVID 19..$^{5-8}$ RT-PCR has multiple limitations such as delayed results availability and the need for specialized laboratory equipment as well as specialized technicians. ${ }^{1,5,6,8}$ As a result, the number of tests performed per day is limited, and the appropriate management of positive cases might be delayed. Therefore, other diagnostic techniques are needed to limit the spread of the virus and effectively monitor the degree of infection in COVID 19 patients. ${ }^{1,5,6,8}$ Current literature explored the possibility of using point-of-care rapid antigen test as it is cost-effective, simple and was used effectively with other viruses such as Influenza and RSV. ${ }^{9}$ However, the studies showed that it had low overall sensitivity and high specificity compared to RT-PCR. ${ }^{1,5,6,8}$

In our study, we are exploring the diagnostic performance of nasal swabs as they do not require a skilled professional in addition to being less time consuming and cause less discomfort. We aim to demonstrate the efficacy of nasal antigen tests in mildly symptomatic cases. This would provide a simple reliable test that might eliminate negative cases with a certain level of confidence. In addition, implementation of such tests will reduce the workload on healthcare professionals, as these tests can be done at clinics or home, and ease the process of reopening.

\section{Objective:}

Determine the accuracy of the nasal swab antigen test in the detection of SARS-COV-2 compared to nasopharyngeal RT-PCR in mildly symptomatic individuals. 
medRxiv preprint doi: https://doi.org/10.1101/2020.11.10.20228973; this version posted December $8,2020$. The copyright holder for this
preprint (which was not certified by peer review) is the author/funder, who has granted medRxiv a license to display the preprint in It is made available under a CC-BY-NC-ND 4.0 International license .

\section{Methods:}

\section{Study population}

The study involved 4183 mild symptomatic individuals. Mild symptomatic individuals definition followed Bahrain protocol ${ }^{10}$. It included symptoms such as fever $\left(<38^{\circ} \mathrm{C}\right)$, loss of taste or smell, flu-like symptoms, sore throat, Gl symptoms, myalgias and fatigue. The study participants were referred to the symptomatic hall in the national testing centre at the exhibition center.

\section{Setting}

All testing was conducted in the symptomatic hall in the National Testing Centre at the Exhibition centre

\section{Study design}

We conducted a cross-sectional study to determine the diagnostic performance of the rapid antigen test compared to RT-PCR. Two swabs were taken from each person, one nasal swab for the antigen test and one nasopharyngeal swab for the RT-PCR. For rapid antigen test, Abbott panbio COVID 19 antigen rapid test device to detect SARS-CoV-2 nucleocapsid protein was used (Abbott Rapid Diagnostic Jena $\mathrm{GmbH}$, Jena, Germany) ${ }^{11}$. The nasopharyngeal samples for RT-PCR were transferred to a viral transport media immediately after collection and transported to a COVID-19 laboratory for testing. The PCR test was conducted using Thermo Fisher Scientific (Waltham, MA) TaqPath 1-Step RTqPCR Master Mix, CG on the Applied Biosystems (Foster City, CA) 7500 Fast Dx RealTime PCR Instrument. The assay used followed the WHO protocol and targeted the E gene. If the E gene was detected, the sample was then confirmed by RdRP and $\mathrm{N}$ genes ${ }^{12}$. The $\mathrm{E}$ gene Ct value was reported and used in this study. Ct values $>40$ were considered negative. Positive and negative controls were included for quality control purposes.

\section{Sample collection:}

All samples were collected by a trained healthcare professional in the National testing centre. The nasal samples were collected, using the nasopharyngeal swab provided with the RADT kit from both nostrils. Based on the CDC guidelines, the patient's head was tilted laid back by $70^{\circ}$, then the swab was inserted by approximately $2 \mathrm{~cm}$ into the nostril while gently rotating it, rolled it several times then removed it.

The nasopharyngeal samples used for PCR were collected through both nostrils from the nasopharynx using a nasopharyngeal swab ${ }^{13}$. The nasopharyngeal swab was inserted into the nostril parallel to the palate until resistance was encountered or the depth was equivalent 
medRxiv preprint doi: https://doi.org/10.1101/2020.11.10.20228973; this version posted December 8, 2020. The copyright holder for this preprint (which was not certified by peer review) is the author/funder, who has granted medRxiv a license to display the preprint in It is made available under a CC-BY-NC-ND 4.0 International license .

to the distance of the nose from the ear. The swab was rolled and rubbed gently, left in place for multiple seconds, then removed slowly while rotating it ${ }^{13}$.

\section{Participants}

- Inclusion criteria:

- suspected COVID 19 cases with mild symptoms (defined by Bahrain protocol ${ }^{10}$ ) presenting to the testing centre

- Exclusion criteria:

- Suspected cases with severe symptoms

- Any asymptomatic suspected case

\section{Data Handling and statistical analysis}

Antigen test results and RT-PCR result with the corresponding Ct value were collected for all mildly symptomatic cases. The diagnostic performance of the antigen was assessed using sensitivity, specificity, positive predictive value, negative predictive value and their respective 95\% Confidence interval. Agreement between nasopharyngeal PCR and nasal antigen tests was assessed using kappa coefficient of agreement. The $\mathrm{Ct}$ value of identified and missed cases by antigen tests were summarized using median and interquartile range. Ct Value of identified and missed cases were compared using a two sample $T$ test. All $P$-values were two-sided and $\mathrm{P}<0.05$ was considered significant. Data collection was performed through a live google sheet and extracted to Microsoft Excel 2016. Statistical analysis was performed using STATA (StataCorp. 2017)

\section{Ethical considerations}

Ethical and research approval was obtained from the National COVID19 research and ethics committee (approval code: CRT-COVID-2020-088). All methods and analysis of data was approved by the National COVID-19 Research and Ethics Committee and carried out in accordance with the local guideline and ethical guidelines of the Declaration of Helsinki 1975. Written Informed consent was waived by the Research and Ethical Committee for this study due to the absence of any patient identifying information. 
medRxiv preprint doi: https://doi.org/10.1101/2020.11.10.20228973; this version posted December 8,2020 . The copyright holder for this preprint (which was not certified by peer review) is the author/funder, who has granted medRxiv a license to display the preprint in It is made available under a CC-BY-NC-ND 4.0 International license .

\section{Results}

A total of 4183 mild symptomatic cases were tested by PCR (using a nasopharyngeal sample) and by antigen test (using a nasal sample). $56.5 \%$ of the cases were males and $43.5 \%$ were females. Mean age of the tested population was $30.9 \mathrm{yrs}$ ( $\pm 14.5 \mathrm{yrs}$ ). Days from symptom onset ranged from 0 to 14 with a median of 2 (IQR 1 - 3). Table1 summarizes the demographics of the tested cohort. $17.5 \%$ (733/4183) of the population tested positive by PCR, no equivocal results were reported. Using the antigen test, $15.1 \%$ were positive, while the remaining tested negative and none of the tests were equivocal.

Out of the 733 confirmed cases by PCR, the antigen test accurately diagnosed 602 cases (82.1\%). 135 cases were falsely negative by the antigen test and 30 cases were reported as false positive. Table 2 is a contingency table showing the PCR and Antigen test results. Using nasopharyngeal RT-PCR as the gold standard test for diagnosis of SARS-CoV2, the rapid antigen test showed a sensitivity of $82.1 \%(95 \% \mathrm{Cl} 79.2 \%-84.8 \%)$ and a specificity of $99.1 \%$ (95\% CI 98.8\% - 99.4\%). With the prevalence of COVID19 being $17.5 \%$ within the tested population, the antigen test had a Positive predictive value (PPV) of $95.3 \%$ and a Negative predictive value (NPV) of $96.3 \%$. Agreement analysis between the nasopharyngeal PCR and the nasal antigen test showed $85.9 \%$ observed agreement $(\mathrm{K}$ coefficient $=0.859$, $\mathrm{p}<0.001)$. Table 3 summarizes the diagnostic performance of the antigen test.

Confirmed cases had a median Ct value of 22 (IQR 20 - 24.1). Cases detected by antigen test had a median Ct value of 22 (IQR 2- to 24) and a mean of 22.1 (95\% Cl 21.9 - 22.4) Cases missed by the antigen test had a median Ct value of 25 (IQR $22-28$ ) and a mean of 25.1 (95\% Cl 24.3 - 25.8). Mean Ct value difference between the false negative and the true positive cases was statistically significant (t-score 9.2, $p<0.001$ ). The median $\mathrm{Ct}$ values and their corresponding interquartile ranges are shown in figure 1.

To control for time since symptom onset as a confounder, we performed a stratified analysis to assess the significance of time since onset of symptoms on the diagnostic performance of the antigen test. Cases with symptom onset within 5 days showed a modest improvement in the diagnostic performance with sensitivity of $82.4 \%$, specificity of $99.3 \%$ and a Kappa coefficient of 0.865 . This was almost similar to cases that had symptom onset within 7 days as shown in Table 4. Additionally, a secondary analysis was conducted after excluding cases with $\mathrm{Ct}$ value more than or equal to 30 and $\mathrm{Ct}$ more than 24 . The sensitivity increased to $84.5 \%$ and $87.9 \%$ respectively. Whereas specificity for both cutoff Ct values was $99.1 \%$. Moreover, after excluding cases with $\mathrm{Ct}$ value $>24$ and restricting symptoms onset to within 
medRxiv preprint doi: https://doi.org/10.1101/2020.11.10.20228973; this version posted December $8,2020$. The copyright holder for this
preprint (which was not certified by peer review) is the author/funder, who has granted medRxiv a license to display the preprint in

It is made available under a CC-BY-NC-ND 4.0 International license

5 days and 7 days, there was a significant increase in sensitivities up to $89.5 \%$ and $89.3 \%$ respectively.

As a follow up, cases that tested negative by the antigen test and tested positive by the RTPCR were asked to repeat the antigen test again within $72 \mathrm{hrs}$. 19 out 135 responded and $73.7 \%$ were positive on the repeated antigen test. 3 of the 30 cases who tested positive by the antigen test but negative by PCR, were tested again within $72 \mathrm{hrs}$. One case tested negative, while two remained positive and were positive by PCR too.

\section{Discussion:}

The PCR has been a very accurate test to diagnose all kinds of infectious diseases. It provides results faster than cultures, and its use for early diagnosis by the infectious disease specialists has been very popular ${ }^{14}$. During the pandemic, PCR test was the only accurate test available to diagnose infected people ${ }^{15}$. PCR is a very sensitive test for SARS-CoV2, and this sensitivity had improved within a few months into the pandemic. Some PCR machines detect down to ten viral RNA copies $\mu \mathrm{l}-1^{16}$. Despite the PCR test's high sensitivity, it has multiple limitations that hold back the efforts in battling this pandemic, especially when reopening had started. Multiple studies showed that RT-PCR was sometimes positive in patients with a corresponding negative culture test for SARS-CoV-2, which indicates that these patients were not infectious ${ }^{8,17}$. This has led to the isolation of people who are noninfectious, and halted reopening measures. Another limitation is that it requires healthcare professionals to collect the swab and to specialized labs and specialists to analyse and interpret the result ${ }^{5,6}$.

As the pandemic necessitated mass testing, the turnaround time extended and required on average 2-3 days in many countries ${ }^{18,19}$. This time limitation has kept Bahrain under-armed when fighting the pandemic. One of the main steps forward to fight this pandemic is to have an accurate test that will detect infectious people - who are a public health risk - and return results quickly. The test should also be easily performed by the general population and can be repeated multiple times whenever necessary. This will reduce the workload on healthcare professionals as well as smoothen the reopening process. The use of the nasopharyngeal swab is a limiting factor in the ease and frequency of testing because it is invasive, uncomfortable and aerosolizing ${ }^{20}$. For similar reasons, the Centers for Disease Control and Prevention (CDC) permitted self-sampling via nasal swabs to compensate for the shortage of healthcare workers and the escalation of COVID 19 cases ${ }^{21}$. Furthermore, the CDC as 

medRxiv preprint doi: https://doi.org/10.1101/2020.11.10.20228973; this version posted December $8,2020$. The copyright holder for this
preprint (which was not certified by peer review) is the author/funder, who has granted medRxiv a license to display the preprint in It is made available under a CC-BY-NC-ND 4.0 International license

well as some studies have illustrated that supervised nasal swabs were quite as effective as nasopharyngeal swabs in detecting SARS-CoV-2 ${ }^{14,22}$.

The antigen test used in our study showed that it can be a reasonable test to be used in this context. The nasal antigen test had a significant agreement correlation of $85 \%$ with the nasopharyngeal PCR in the studied population. The mild to moderate symptomatic population represent the majority of cases within COVID19, $81 \%$ as reported by a Chinese cohort ${ }^{23}$. Hence targeting this population should be a priority when using a newer test. In cases where patients present with severe disease, PCR test should continue to be used as having a definite result is necessary.

The rapid antigen detection test (RADT) in our study had a very high specificity of $99.3 \%$. The test also had high predictive value within a population with a $18 \%$ prevalence of COVID 19. The sensitivity of the test was $82.1 \%$ when compared to the PCR test. Despite the antigen test having lower sensitivity, it was done using a nasal and not a nasopharyngeal sample. Moreover the diagnostic accuracy of PCR can never be compared to rapid point of care antigen test as the method of detection is different.

The findings in our study regarding the diagnostic performance of the rapid antigen test match the data in the current literature to a certain extent. For example, a review of nine studies involving 7 different brands of rapid antigen tests reported that all studies reported very high specificities. The pooled specificity was 99\% (95\% Cl $98-100 \%)$ which was similar to our test's specificity $(99.2 \%)$. However the reported pooled sensitivity was $49 \%(95 \% \mathrm{Cl}$ 28 - 70) which is completely different from our test's sensitivity (81.3\%). There was a wide range of the sensitivities across the studies from 0 to $94 \%{ }^{24}$. Few high quality studies showed that some tests such as the Bioeasy 2019-nCov Ag Fluorescence Rapid Test Kit had a relatively high pooled sensitivity of $82.3 \%$, which is slightly close to our test's sensitivity ${ }^{25}$.

There were multiple studies that reported either low sensitivities such as $30 \%$ and $50 \%$ or low cohen's coefficient of agreement while in our study the reported sensitivity was $81.3 \% 5$, ${ }^{7,26}$. All of the aforementioned studies were using different commercial antigen tests as well as different swabs (nasopharyngeal swabs and nasal swabs). Moreover, most of the studies did not specify the severity of symptoms within the study population. The studies that reported very high sensitivities of the rapid antigen test usually involved patients who were either in the emergency department or hospitalised. Such patients are usually more symptomatic, hence have a higher viral load. As a result, the reported sensitivities were higher compared to patients with milder symptoms ${ }^{27-30}$. 

medRxiv preprint doi: https://doi.org/10.1101/2020.11.10.20228973; this version posted December $8,2020$. The copyright holder for this
preprint (which was not certified by peer review) is the author/funder, who has granted medRxiv a license to display the preprint in It is made available under a CC-BY-NC-ND 4.0 International license .

The cases missed by the antigen test in our study had higher Ct Value than those detected by the antigen test. The mean Ct value for the missed cases was 25.1. Bullard et al described that viral cultures fail when time from symptom onset exceeds 8 days and/or the ct value exceeds $24{ }^{31}$. When we excluded cases above $\mathrm{Ct}$ value of 24 , the sensitivity improved to $87.9 \%$ with an aggremention rate (Kappa Coefficient) of 89.2 between nasal antigen test and nasopharyngeal PCR. The accuracy improved further when symptom onset was restricted to 7 days and cases above Ct of 24 were excluded. The agreement coefficient reached $91.3 \%$ and sensitivity reached $89.3 \%$ without affecting specificity. This finding was also reported by Bayona et al in a meta analysis conducted on multiple RADT, the sensitivity of the RADT was higher when performed in patients early in the disease ( 0 - 7 days) compared to tests performed late in the disease ( $8-14$ days). The study also showed that the reduction of the $\mathrm{Ct}$ value from $\leq 40$ to $\leq 30$ increased the sensitivity of the rapid antigen test from $68 \%$ to $98 \%$. One of the studies included in the meta-analysis showed that the sensitivity improved to $82.2 \%$ in patients with higher viral loads $(\mathrm{Ct} \text { value }<25)^{7}$. In addition, the median $\mathrm{Ct}$ value of antigen test negative cases was higher and significantly different from positive cases ${ }^{7}$. The antigen test's sensitivity significantly improves when cases with high Ct values (30 - 40) were removed from the analysis ${ }^{24,32}$., and this was also proven by our study as shown in table 4.

In order to implement the use of point of care (POC) rapid antigen testing in clinics as well as by the public, we need to improve the efficacy of the test by testing and implementing a scheme that would limit the number of false negative cases, especially in symptomatic patients. We believe that increasing the frequency of the test can improve its diagnostic accuracy. As seen in the sample of 22 patients who had false results by the antigen test in our study, the repeated test showed accurate results in $77 \%$ of the repeated test. We have proposed an algorithm that can further improve the diagnostic accuracy of the test in symptomatic patients. The RADT must not be used if more than 7 days have passed since symptoms onset or if the patient has severe symptoms. If the RADT was negative, then the patient must repeat the test again to confirm a negative result by the antigen test. Any positive RADT necessitate further testing by PCR to confirm the infection. This algorithm however should be examined to understand the value of repeating an antigen test in those cases. Moreover, the time frame to repeat the RADT has to be experimented to better understand an appropriate time range to improve the efficacy of the scheme. The definition of mild symptoms must be clearly understood by the public. If a person had severe symptoms or was a high risk individual (close contact), they must perform a RT-PCR as these are higher risk populations and they require a more accurate diagnosis. It is necessary 
medRxiv preprint doi: https://doi.org/10.1101/2020.11.10.20228973; this version posted December 8, 2020. The copyright holder for this preprint (which was not certified by peer review) is the author/funder, who has granted medRxiv a license to display the preprint in

It is made available under a CC-BY-NC-ND 4.0 International license .

to keep in mind that PCR test is the gold standard test for COVID 19 and that the antigen test can be used in addition to PCR as part of the testing strategies for COVID 19. The use of antigen test can potentially decrease the use of PCR test.

Given the high specificity shown by the RADT, we believe that it can be adequately used in asymptomatic individuals who are not close contacts. The RADT can be used in different settings (gatherings, schools, workplaces) to conduct frequent monitoring of the population and help in identifying cases early to prevent an outbreak. However, its diagnostic accuracy in these settings has to be examined to determine its efficacy.

The study has several strengths. The large sample size and the comparison of nasal swab tested by RADT to Nasopharyngeal samples tested by PCR are the two main strengths in this study. Moreover the use of a single large testing centre allowed standardization and increased quality in sample and data collection. All nasopharyngeal samples were transported and tested in a single lab using the same kits and machines and hence standardizing the results and $\mathrm{Ct}$ values. The study has its limitations, the nasal sample was collected using nasopharyngeal swabs. Nasopharyngeal swabs are flexible and smaller and hence are more difficult to collect nasal samples. Therefore, this could have underestimated the results of the study. Moreover, the clinical symptoms of the participants were not collected and there were significant amounts of missing data on time from symptom onset. This had led to a decrease in sample size when testing different models based on restriction of time from symptom onset. This can either under or overestimate the results for the restricted models. Only a small number of cases agreed to have a repeated test after discrepancy in PCR and RADT results. The timing of the repeat test ranged from 24 to $72 \mathrm{hrs}$ and wasn't standardized due to logistical difficulties.

\section{Conclusion}

The sensitivity of rapid antigen test is affected by numerous factors including the viral load, days of symptoms, route of sample collection, and the test mode. The results of the diagnostic assessment of nasal swabs in the RADT used in our study are promising regarding the potential benefit of using them as a screening tool in mildly symptomatic patients. The diagnostic ability was especially high in cases with high viral load. Further investigations ought to be performed to test the algorithms of repeated testing using RADT to further improve its diagnostic ability. More research is required to assess the ability of the RADT to screen large populations with low disease prevalence. It is also important to note that the rapid antigen test is intended to be used alongside RT-PCR and not replace it. RADT can be of benefit in reducing the use of PCR. 
medRxiv preprint doi: https://doi.org/10.1101/2020.11.10.20228973; this version posted December 8, 2020. The copyright holder for this preprint (which was not certified by peer review) is the author/funder, who has granted medRxiv a license to display the preprint in It is made available under a CC-BY-NC-ND 4.0 International license

\section{Tables:}

Table 1. Demographics and clinical features of studied sample

\begin{tabular}{|l|l|l|}
\hline Variables & N & Value \\
\hline Age in years - Mean \pm SD & 4183 & $30.9 \pm 14.5$ \\
\hline Male - no. (\%) & 4183 & $2365(56.5 \%)$ \\
\hline Symptoms Onset in days - Median (IQR) & 1301 & $2(1-3)$ \\
\hline Prevalence - no. (\%) & 4183 & $733(17.5 \%)$ \\
\hline Ct Value of PCR positive cases - Median (IQR) & 530 & $22(20-24.5)$ \\
\hline
\end{tabular}

Table 2: 2x2 table showing the PCR and Antigen test results

\begin{tabular}{|c|c|c|c|}
\hline & PCR Positive & PCR Negative & Total Antigen Results \\
\hline Antigen Test Positive & $\begin{array}{c}602 \\
\text { True Positive }\end{array}$ & $\begin{array}{c}30 \\
\text { False Positive }\end{array}$ & 632 \\
\hline Antigen Test Negative & $\begin{array}{c}131 \\
\text { False Negative }\end{array}$ & $\begin{array}{c}3420 \\
\text { True Negative }\end{array}$ & 3551 \\
\hline Total PCR Results & 733 & 3450 & Total Cases: 4183 \\
\hline
\end{tabular}

Table 3: Assessment of the diagnostic accuracy of the antigen test

\begin{tabular}{|c|c|c|c|}
\hline & Value & \multicolumn{2}{|c|}{$95 \%$ Cl } \\
\hline Prevalence & $17.5 \%$ & $16 \%$ & $84.8 \%$ \\
\hline Sensitivity & $82.1 \%$ & $79.2 \%$ & $99.4 \%$ \\
\hline Specificity & $99.1 \%$ & $98.8 \%$ & $96.8 \%$ \\
\hline Positive Predicted Value & $95.3 \%$ & $93.3 \%$ & $96.9 \%$ \\
\hline Negative Predicted Value & $96.3 \%$ & $95.6 \%$ & 135 \\
\hline Positive Likelihood Ratio & 94.4 & 66 & 0.211 \\
\hline Negative Likelihood Ratio & 0.18 & 0.154 & $4.4 \%$ \\
\hline False Discovery Rate & $3.8 \%$ & $3.3 \%$ & $83.8 \%$ to $88 \%(p<0.001)$ \\
\hline Kappa Coefficient & $85.9 \%$ & & \\
\hline
\end{tabular}


medRxiv preprint doi: https://doi.org/10.1101/2020.11.10.20228973; this version posted December 8, 2020. The copyright holder for this preprint (which was not certified by peer review) is the author/funder, who has granted medRxiv a license to display the preprint in perpetuity.

It is made available under a CC-BY-NC-ND 4.0 International license .

Table 4: The effect of symptoms onset time and Ct values on the diagnostic performance

\begin{tabular}{|c|c|c|c|c|c|c|c|}
\hline & Model & $\mathbf{N}$ & Prevalence & Sensitivity & Specificity & Negative Predicted Value & $\begin{array}{c}\text { Positive Predicted } \\
\text { Value }\end{array}$ \\
\hline 1 & $\begin{array}{c}\text { Symptom onset within } \\
7 \text { days }\end{array}$ & 1290 & $\begin{array}{c}20 \% \\
(18 \%-22.8 \%)\end{array}$ & $\begin{array}{c}82.6 \% \\
(77.5 \%-87 \%)\end{array}$ & $\begin{array}{c}99.3 \% \\
(98.6 \%-99.7 \%)\end{array}$ & $\begin{array}{c}95.7 \% \\
(94.3 \%-96.8 \%)\end{array}$ & $\begin{array}{c}96.9 \% \\
(93.7 \%-98.7 \%)\end{array}$ \\
\hline 2 & $\begin{array}{l}\text { Symptom onset within } \\
5 \text { days }\end{array}$ & 1252 & $\begin{array}{c}20 \% \\
(18 \%-22.8 \%)\end{array}$ & $\begin{array}{c}82.4 \% \\
(77.2 \%-86.9 \%)\end{array}$ & $\begin{array}{c}99.3 \% \\
(98.6 \%-99.7 \%)\end{array}$ & $\begin{array}{c}95.6 \% \\
(94.2 \%-96.8 \%)\end{array}$ & $\begin{array}{c}96.8 \% \\
(93.5 \%-98.7 \%)\end{array}$ \\
\hline 3 & $\begin{array}{l}\text { Excluding cases with } \\
\qquad \mathrm{Ct} \geq 30\end{array}$ & 4148 & $\begin{array}{c}17 \% \\
(16 \%-18.1 \%)\end{array}$ & $\begin{array}{c}84.5 \% \\
(81.6 \%-87.1 \%)\end{array}$ & $\begin{array}{c}99.1 \% \\
(98.8 \%-99.4 \%)\end{array}$ & $\begin{array}{c}96.9 \% \\
(96.3 \%-97.5 \%)\end{array}$ & $\begin{array}{c}95.2 \% \\
(93.2 \%-96.7 \%)\end{array}$ \\
\hline 4 & $\begin{array}{l}\text { Excluding cases with } \\
\text { Ct }>24\end{array}$ & 3996 & $\begin{array}{c}14 \% \\
(13 \%-15 \%)\end{array}$ & $\begin{array}{c}87.9 \% \\
(84.9 \%-90.5 \%)\end{array}$ & $\begin{array}{c}99.1 \% \\
(98.8 \%-99.4 \%)\end{array}$ & $\begin{array}{c}98.1 \% \\
(97.6 \%-98.5 \%)\end{array}$ & $\begin{array}{c}94.2 \% \\
(91.8 \%-96.1 \%)\end{array}$ \\
\hline 5 & $\begin{array}{c}\text { Symptom onset within } \\
7 \text { days and Excluding } \\
\text { cases with } \mathrm{Ct} \geq 30\end{array}$ & 1274 & $\begin{array}{c}20 \% \\
(17 \%-21.8 \%)\end{array}$ & $\begin{array}{c}86.3 \% \\
(81.4 \%-90.4 \%)\end{array}$ & $\begin{array}{c}99.3 \% \\
(98.6 \%-99.7 \%)\end{array}$ & $\begin{array}{c}96.8 \% \\
(95.5 \%-97.8 \%)\end{array}$ & $\begin{array}{c}96.8 \% \\
(93.6 \%-98.7 \%)\end{array}$ \\
\hline 6 & $\begin{array}{c}\text { Symptom onset within } \\
7 \text { days and Excluding } \\
\text { cases with } \mathrm{Ct}>24\end{array}$ & 1220 & $\begin{array}{c}16 \% \\
(14 \%-18.3 \%)\end{array}$ & $\begin{array}{c}89.3 \% \\
(84.2 \%-93.3 \%)\end{array}$ & $\begin{array}{c}99.3 \% \\
(98.6 \%-99.7 \%)\end{array}$ & $\begin{array}{c}98 \% \\
(96.9 \%-98.7 \%)\end{array}$ & $\begin{array}{c}96.2 \% \\
(92.3 \%-98.4 \%)\end{array}$ \\
\hline 7 & $\begin{array}{c}\text { Symptom onset within } \\
5 \text { days and Excluding } \\
\text { cases with } \mathrm{Ct}>30\end{array}$ & 1236 & $\begin{array}{c}19 \% \\
(17 \%-21.8 \%)\end{array}$ & $\begin{array}{c}86.3 \% \\
(81.3 \%-90.4 \%)\end{array}$ & $\begin{array}{c}99.3 \% \\
(98.6 \%-99.7 \%)\end{array}$ & $\begin{array}{c}96.8 \% \\
(95.5 \%-97.8 \%)\end{array}$ & $\begin{array}{c}96.7 \% \\
(93.4 \%-98.7 \%)\end{array}$ \\
\hline 8 & $\begin{array}{c}\text { Symptom onset within } \\
5 \text { days and Excluding } \\
\text { cases with } \mathrm{Ct}>24\end{array}$ & 1184 & $\begin{array}{c}16 \% \\
(14 \%-18.3 \%)\end{array}$ & $\begin{array}{c}89.5 \% \\
(84.2 \%-93.5 \%)\end{array}$ & $\begin{array}{c}99.3 \% \\
(98.6 \%-99.7 \%)\end{array}$ & $\begin{array}{c}98 \% \\
(96.9 \%-98.8 \%)\end{array}$ & $\begin{array}{c}96 \% \\
(92 \%-98.4 \%)\end{array}$ \\
\hline
\end{tabular}

\section{Figures:}

\section{Box plot of PCR Ct value and Antigen test results}

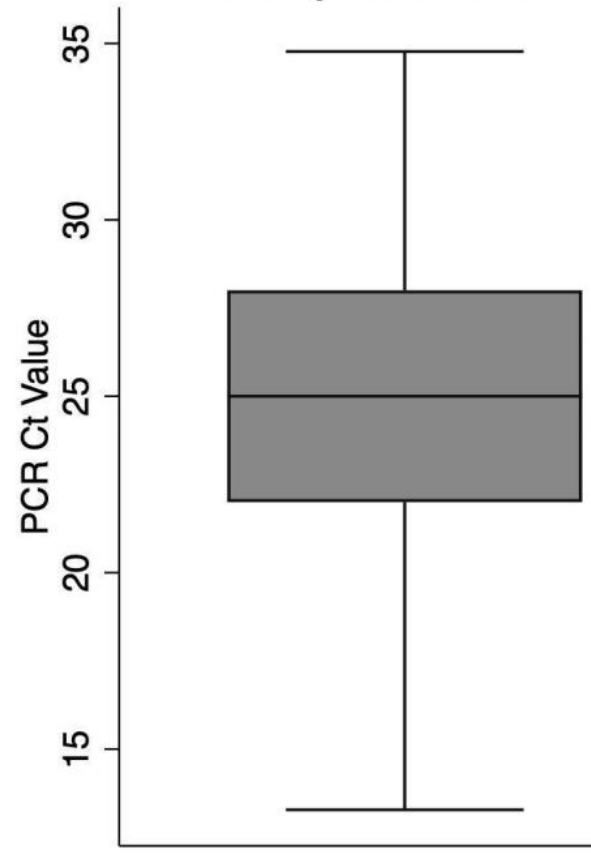

Missed by Antigen test

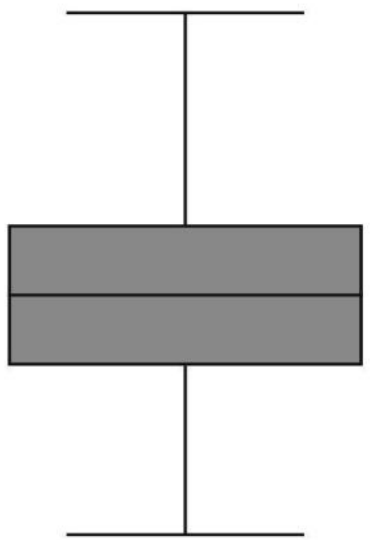

Figure 1. Comparison of the median $\mathrm{Ct}$ values between detected and missed cases by the antigen test 
medRxiv preprint doi: https://doi.org/10.1101/2020.11.10.20228973; this version posted December 8, 2020. The copyright holder for this preprint (which was not certified by peer review) is the author/funder, who has granted medRxiv a license to display the preprint in It is made available under a CC-BY-NC-ND 4.0 International license

\section{References}

1. Hirotsu $Y$, Maejima M, Shibusawa M, et al. Comparison of automated SARSCoV-2 antigen test for COVID-19 infection with quantitative RT-PCR using 313 nasopharyngeal swabs, including from seven serially followed patients. International Journal of Infectious Diseases. 2020;99:397-402.

2. Seo G, Lee G, Kim MJ, et al. Rapid detection of COVID-19 causative virus (SARS-CoV-2) in human nasopharyngeal swab specimens using field-effect transistor-based biosensor. ACS nano. 2020;14(4):5135-5142.

3. Organization WH. WHO Coronavirus Disease (COVID-19) Dashboard https://covid19. who.int/?gclid=Cj0KCQjwt4X8BRCPARIsABmcnOoJcjBpREmwzoTM8ZpnEbH5VetPpDrlY230YRl1b2rt0q44TGw2rgaAoADEALw wcB 4. $\quad$ Bahrain MoH-Ko. Daily COVID 19 Report. Updated 8/11/2020. https://healthalert.gov.bh/en/

5. Scohy A, Anantharajah A, Bodéus M, Kabamba-Mukadi B, Verroken A, Rodriguez-Villalobos $\mathrm{H}$. Low performance of rapid antigen detection test as frontline testing for COVID-19 diagnosis. Journal of Clinical Virology. 2020:104455.

6. Porte L, Legarraga $P$, Vollrath V, et al. Evaluation of novel antigen-based rapid detection test for the diagnosis of SARS-CoV-2 in respiratory samples. International Journal of Infectious Diseases. 2020;

7. Lambert-Niclot S, Cuffel A, Le Pape S, et al. Evaluation of a rapid diagnostic assay for detection of SARS CoV-2 antigen in nasopharyngeal swab. Journal of clinical microbiology. 2020;

8. Carter LJ, Garner LV, Smoot JW, et al. Assay techniques and test development for COVID-19 diagnosis. ACS Publications; 2020.

9. Clerc O, Greub G. Routine use of point-of-care tests: usefulness and application in clinical microbiology. Clinical Microbiology and Infection.

2010;16(8):1054-1061.

10. (COVID-19) TNTfCtC. Bahrain COVID-19 National Protocols. 2020. https://www.nhra.bh/Media/Announcement/MediaHandler/GenericHandler/document s/Announcements/NHRA News MOH\%20ALERT Bahrain\%20COVID19\%20National\%20Protocols 20200701.pdf

11. Linares $M$, Pérez-Tanoira $R$, Carrero $A$, et al. Panbio antigen rapid test is reliable to diagnose SARS-CoV-2 infection in the first 7 days after the onset of symptoms. Journal of Clinical Virology. 2020:104659.

12. Organization WH. Diagnostic detection of 2019-nCoV by real-time RT- PCR. 2020;2. https://www.who.int/docs/default-source/coronaviruse/protocol-v2-1.pdf

13. Prevention CfDCa. Interim Guidelines for Collecting, Handling, and Testing Clinical Specimens for COVID-19 2020. Updated April 292020.

https://www.cdc.gov/coronavirus/2019-ncov/lab/guidelines-clinical-specimens.html.

14. Menon $\mathrm{P}$, Kapila K, Ohri V. Polymerase chain reaction and advances in infectious disease diagnosis. Medical Journal Armed Forces India. 1999;55(3):229231.

15. Patel A, Jernigan DB. Initial public health response and interim clinical guidance for the 2019 novel coronavirus outbreak-United States, December 31, 2019-February 4, 2020. Morbidity and Mortality Weekly Report. 2020;69(5):140. 16. Vogels CB, Brito AF, Wyllie AL, et al. Analytical sensitivity and efficiency comparisons of SARS-CoV-2 RT-qPCR primer-probe sets. Nature microbiology. 2020;5(10):1299-1305. 
medRxiv preprint doi: https://doi.org/10.1101/2020.11.10.20228973; this version posted December 8, 2020. The copyright holder for this preprint (which was not certified by peer review) is the author/funder, who has granted medRxiv a license to display the preprint in It is made available under a CC-BY-NC-ND 4.0 International license

17. Cento V, Colagrossi L, Nava A, et al. Persistent positivity and fluctuations of SARS-CoV-2 RNA in clinically-recovered COVID-19 patients. Journal of Cleaner Production. 2020;

18. Young S, Taylor SN, Cammarata CL, et al. Clinical evaluation of BD Veritor SARS-CoV-2 point-of-care test performance compared to PCR-based testing and versus the Sofia 2 SARS Antigen point-of-care test. Journal of Clinical Microbiology. 2020;

19. HRS A. Massachusetts Health Center COVID-19 Survey Summary Report 2020. Updated 16 october 2020. https://bphc.hrsa.gov/emergencyresponse/coronavirus-health-center-data/ma

20. Ikeda M, Imai K, Tabata S, et al. Clinical evaluation of self-collected saliva by RT-qPCR, direct RT-qPCR, RT-LAMP, and a rapid antigen test to diagnose COVID19. medRxiv. 2020;

21. Ravi N, Cortade DL, Ng E, Wang SX. Diagnostics for SARS-CoV-2 detection: A comprehensive review of the FDA-EUA COVID-19 testing landscape. Biosensors and Bioelectronics. 2020;165:112454.

22. Kojima N, Turner F, Slepnev V, et al. Self-Collected Oral Fluid and Nasal Swabs Demonstrate Comparable Sensitivity to Clinician Collected Nasopharyngeal Swabs for Covid-19 Detection. medRxiv. 2020;

23. Liu Z, Bing X. ZaZhi X. Novel Coronavirus Pneumonia Emergency Response Epidemiology Team[The epidemiological characteristics of an outbreak of 2019 novel coronavirus diseases (COVID-19) in China]. 2020;41:145-151.

24. Bayona HHG, Cabaluna ITG, Dans A, Dans LF. Should rapid antigen tests be used as a screening tool for COVID-19?

25. Weitzel T, Legarraga $P$, Iruretagoyena M, et al. Head-to-head comparison of four antigen-based rapid detection tests for the diagnosis of SARS-CoV-2 in respiratory samples. bioRxiv. 2020;

26. Blairon L, Wilmet A, Beukinga I, Tré-Hardy M. Implementation of rapid SARSCoV-2 antigenic testing in a laboratory without access to molecular methods: experiences of a general hospital. Journal of Clinical Virology. 2020:104472. 27. Liu Y, Liao W, Wan L, Xiang T, Zhang W. Correlation between relative nasopharyngeal virus RNA load and lymphocyte count disease severity in patients with COVID-19. Viral immunology. 2020;

28. $Y u$ X, Sun S, Shi Y, Wang H, Zhao R, Sheng J. SARS-CoV-2 viral load in sputum correlates with risk of COVID-19 progression. Critical Care. 2020;24:1-4. 29. Wang $Y$, Zhang L, Sang L, et al. Kinetics of viral load and antibody response in relation to COVID-19 severity. The Journal of clinical investigation. 2020;130(10) 30. Pujadas E, Chaudhry F, McBride R, et al. SARS-CoV-2 Viral Load Predicts COVID-19 Mortality. medRxiv. 2020;

31. Bullard J, Dust K, Funk D, et al. Predicting infectious SARS-CoV-2 from diagnostic samples. Clinical Infectious Diseases. 2020;

32. Diao B, Wen K, Chen J, et al. Diagnosis of acute respiratory syndrome coronavirus 2 infection by detection of nucleocapsid protein. medRxiv. 2020; 
medRxiv preprint doi: https://doi.org/10.1101/2020.11.10.20228973; this version posted December 8, 2020. The copyright holder for this preprint (which was not certified by peer review) is the author/funder, who has granted medRxiv a license to display the preprint in It is made available under a CC-BY-NC-ND 4.0 International license.

\section{DECLARATIONS}

Conflict of interest: The authors have declared that no conflict of interest exists.

Ethics approval and consent to participate: The study was approved by the National COVID- 19 Research and Ethics Committee.

Consent for publication: All authors gave their consent for publication.

Availability of data and materials: All the data for this study will be made available upon reasonable request to the corresponding author.

Funding: No funding was received to perform this study.

Author contributions: $A A$ and FM analysed the data and wrote the manuscript. QA, BA and AIA performed data collection. AA and $M Q$ interpreted data and edited the manuscript. MA supervised data collection, data analysis and edited the manuscript. All authors reviewed and approved the final version of the manuscript. Manaf Alqahtani is the guarantor of this work. 